University of Nebraska - Lincoln

DigitalCommons@University of Nebraska - Lincoln

2006

\title{
Survival of Adult Female Elk in Yellowstone Following Wolf Restoration
}

Shaney Evans

University of Minnesota

L. David Mech

USGS Northern Prairie Wildlife Research Center, david_mech@usgs.gov

P. J. White

Yellowstone National Park

Glen A. Sergeant

USGS Northern Prairie Wildlife Research Center

Follow this and additional works at: https://digitalcommons.unl.edu/usgsnpwrc

Part of the Other International and Area Studies Commons

Evans, Shaney; Mech, L. David; White, P. J.; and Sergeant, Glen A., "Survival of Adult Female Elk in Yellowstone Following Wolf Restoration" (2006). USGS Northern Prairie Wildlife Research Center. 102. https://digitalcommons.unl.edu/usgsnpwrc/102

This Article is brought to you for free and open access by the US Geological Survey at DigitalCommons@University of Nebraska - Lincoln. It has been accepted for inclusion in USGS Northern Prairie Wildlife Research Center by an authorized administrator of DigitalCommons@University of Nebraska - Lincoln. 


\title{
Survival of Adult Female Elk in Yellowstone Following Wolf Restoration
}

\author{
SHANEY B. EVANS, Department of Fisheries, Wildlife, and Conservation Biology, University of Minnesota, St. Paul, MN 55108, USA \\ L. DAVID MECH, ${ }^{\mathbf{1}, \mathbf{2}}$ Biological Resources Division, United States Geological Survey, Northern Prairie Wildlife Research Center, Jamestown, \\ ND 58401, USA \\ P. J. WHITE, National Park Service, Yellowstone National Park, Mammoth, WY 82190, USA \\ GLEN A. SARGEANT, Biological Resources Division, United States Geological Survey, Northern Prairie Wildlife Research Center, \\ Jamestown, ND 58401, USA
}

\begin{abstract}
Counts of northern Yellowstone elk (Cervus elaphus) in northwestern Wyoming and adjacent Montana, USA, have decreased at an average rate of 6-8\% per year since wolves (Canis lupus) were reintroduced in 1995. Population growth rates of elk are typically sensitive to variations in adult female survival; populations that are stable or increasing exhibit high adult female survival. We used survival records for 85 radiocollared adult female elk 1-19 years old to estimate annual survival from March 2000 to February 2004. Weighted average annual survival rates were approximately $0.83(95 \% \mathrm{Cl}=0.77-0.89)$ for females $1-15$ years old and $0.80(95 \% \mathrm{Cl}$ $=0.73-0.86$ ) for all females. Our estimates were much lower than the rate of 0.99 observed during 1969-1975 when fewer elk were harvested by hunters, wolves were not present, and other predators were less numerous. Of 33 documented deaths included in our analysis, we attributed 11 to hunter harvest, 14 to predation (10 wolf, 2 unknown, 1 cougar [Puma concolor], and 1 bear [Ursus $s p]),$.6 to unknown causes, and 2 to winter-kill. Most deaths occurred from December through March. Estimates of cause-specific annual mortality rates were $0.09(0.05-0.14)$ for all predators, $0.08(0.04-0.13)$ for hunting, and $0.07(0.03-0.11)$ for wolves specifically. Wolf-killed elk were typically older (median $=12 \mathrm{yr}$ ) than hunter-killed elk (median $=9 \mathrm{yr}, \mathrm{P}=0.03$ ). However, elk that winter outside the park where they were exposed to hunting were also younger (median $=7 \mathrm{yr}$ ) than elk that we did not observe outside the park (median $=9 \mathrm{yr}, \mathrm{P}<0.01$ ). Consequently, differences in ages of elk killed by wolves and hunters may reflect characteristics of elk exposed to various causes of mortality, as well as differences in susceptibility. Unless survival rates of adult females increase, elk numbers are likely to continue declining. Hunter harvest is the only cause of mortality that is amenable to management at the present time. (JOURNAL OF WILDLIFE MANAGEMENT 70(5):1372-1378; 2006)
\end{abstract}

\section{Key words}

Canis lupus, Cervus elaphus, elk, hunting, mortality, predator-prey, radiotelemetry, survival, wolves, Yellowstone.

Of population processes affecting large mammals, mortality rates of prime-aged animals have by far the dominant impact on population growth (Eberhardt 2002). Prior to the restoration of wolves into Yellowstone National Park, USA, during 1995, survival of adult female Yellowstone elk was typically high $(>0.90)$ and relatively constant (Houston 1982, Taper and Gogan 2002, Garrott et al. 2003). The primary causes of mortality for adult female elk were hunter harvests of elk that migrated out of the park and winter-kill. Survival of older females decreased as snow-pack severity increased, but severity did not directly affect survival of prime-aged females, except during the most extreme winters (Singer et al. 1989, Coughenour and Singer 1996, Garrott et al. 2003). However, increasing snow pack indirectly influenced the survival of prime-aged females by increasing the number of elk wintering at relatively lower elevations outside the park and, in turn, the number of elk harvested (Natl. Res. Counc. 2002, White et al. 2003). For example, the number of northern Yellowstone elk harvested during the Gardiner Late Elk Hunt in Montana, USA, had a positive correlation with winter severity and hunter success

1 E-mail: mechx002@umn.edu

2 Mailing address: The Raptor Center, University of Minnesota, St. Paul, MN 55108, USA approximated $95 \%$ during years with high snow water equivalent.

Trend counts indicate that the abundance of northern Yellowstone elk has decreased at an average rate of approximately 6-8\% per year since 1994, from approximately 17,000 elk counted during winter 1995 , when wolves were first reintroduced, to 8,335 elk counted in winter 2004 (Fig. 1). Predation by wolves and human harvests were the dominant causes of mortality for adult female elk during this period (White et al. 2003, Wright et al. 2005). The extent to which wolf predation was an additive component of elk mortality or simply compensated for winter starvation, hunting, and mortality by other predators was unknown.

One analysis of the northern Yellowstone herd concluded that wolf predation was primarily compensatory (Vucetich et al. 2005), whereas others concluded that it was additive (White and Garrott 2005, Varley and Boyce 2006). Although assessments have been made of the effect of wolf predation on other Yellowstone elk herds, the results have been inconsistent (Garrott et al. 2005) in keeping with longstanding cautions that the effects of predators on prey are highly variable over time, space, and species (Mech 1970:268). The consequences of additive mortality for adult females would be to decrease the growth rate of the population, resulting either in less pronounced growth or a decrease in abundance. 


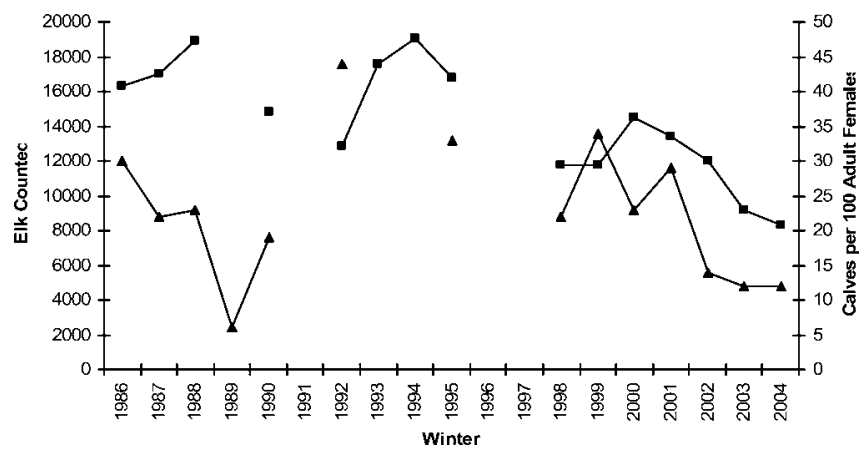

Figure 1. Annual winter counts (squares) and calves per 100 adult females (triangles) of northern Yellowstone elk in Yellowstone National Park and adjacent areas of Montana, USA, 1986-2004 (Northern Yellowstone Cooperative Wildlife Working Group 2003). We did not adjust counts for uncertain detection.

Our study objectives were to 1) estimate survival rates of northern Yellowstone adult female elk, 2) compare survival and causes of death to estimates obtained prior to wolf restoration, and 3) assess the likely effects of observed survival rates and limiting factors on population trends.

\section{Study Area}

The high mountains and plateaus of Yellowstone provided summer range for an estimated 20,000-25,000 elk from 7 to 8 herds (i.e., northern Yellowstone, Madison-Firehole, Clarks Fork, Cody [i.e., North Fork Shoshone, Carter Mountain], Jackson, Sand Creek/Bechler, and Gallatin River). Elk from different herds intermingled during summer, but migrated to separate winter ranges located primarily outside the park owing to snowfalls that accumulated more than $3 \mathrm{~m}$ in depth on interior plateaus. Only the Madison-Firehole and northern herds wintered primarily within the park.

Northern Yellowstone elk constituted the largest elk population in Yellowstone National Park, with maximum counts of $>19,000$ during the mid-1990s. These elk wintered on approximately $1,500 \mathrm{~km}^{2}$ of foothills and valley

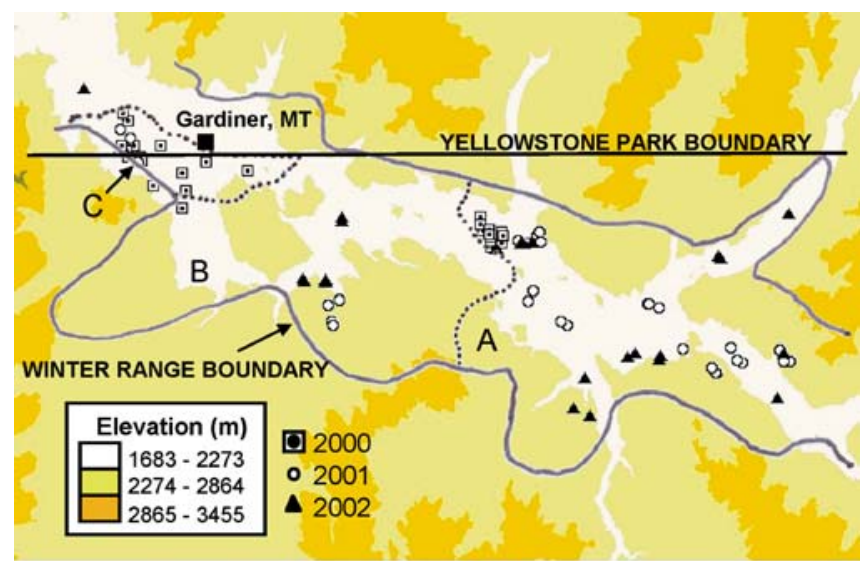

Figure 2. Locations of cow elk captured during 2000-2002 in the northern winter range of Yellowstone National Park, USA, illustrating park boundary. (A) Upper winter range, (B) lower winter range, and (C) boundary area by Gardiner, Montana, USA (Houston 1982). We excluded locations of 16 elk captured in 2000 because we did not record their precise capture locations (Cook et al. 2004). bottoms along the Gardiner, Lamar, and Yellowstone rivers in the northern portion of the park and adjacent areas of Montana (Lemke et al. 1998; Fig. 2). Relatively few elk remained on the northern range throughout the year. The majority of northern Yellowstone elk migrated to summer ranges along the east-central boundary of the park, north of the park onto the Buffalo Plateau, and as far south as Lewis Lake (approx. 50 km; S. B. Evans, University of Minnesota, unpublished data).

Elevations within the northern wintering area ranged from $1,500 \mathrm{~m}$ in river drainages to $3,400 \mathrm{~m}$ on mountaintops. The lower-elevation vegetation was primarily open grasslandsagebrush steppe $(37 \%)$ with interspersed upland grasslands, wet meadows, and non-vegetated areas (19\%; Houston 1982, Despain 1990). Dominant plant species included Idaho fescue (Festuca idahoensis), blue-bunch wheatgrass (Pseudoroegneria spicata), and big sagebrush (Artemisia tridentata). However, coniferous forests of Douglas-fir (Pseudotsuga menziesii), Engelmann spruce (Picea engelmannii), lodgepole pine (Pinus contorta), subalpine fir (Abies lasiocarpa), and whitebark pine (Pinus albicaulis) were interspersed (44\%) and occurred at higher elevations (Houston 1982, Despain 1990). Coniferous forests were more prevalent throughout the summer range. Large-scale fires during 1988 burned approximately $40 \%$ of these ranges, creating a complex mosaic of burned and unburned forests at different stages of succession (Singer et al. 1989, Despain 1990).

Short, cool summers and long, cold winters with a mean annual temperature of $1.8^{\circ} \mathrm{C}$ on the northern range characterized the climate of Yellowstone National Park (Houston 1982). Mean annual precipitation varied from approximately $25 \mathrm{~cm}$ in the Gardiner basin to $35 \mathrm{~cm}$ in the upper Lamar River valley (Coughenour and Singer 1996). During this study, the winters of 2000-2003 were relatively mild, as indexed by estimating daily snow water equivalent (SWE) from the Tower Falls Climate Impact Meteorological station (located in the mid-elevation zone [1,909 m] of the winter range) and summing daily estimates from 1 October through 31 April $\left(\mathrm{SWE}_{\mathrm{ACC}}\right)$. The $\mathrm{SWE}_{\mathrm{ACC}}$ for winter 2000 was $1,109 \mathrm{~cm}$, which was close to the historic average of 1,009 cm during 1949-2004 (Farnes et al. 1999; unpublished data). However, $\mathrm{SWE}_{\mathrm{ACC}}$ for winters during 2001-2003 were well below the historic average at 467, 656, and $541 \mathrm{~cm}$, respectively. The northern range experienced a drought during the study, and April-July precipitation during 2000-2003 (13.8-17.2 cm) was below the historic average of $17.6 \mathrm{~cm}$ during 1949-2004 (Farnes et al. 1999; unpublished data).

The northern range supported an intact, diverse predatorprey complex, with 8 ungulate species and 6 large predators. Midwinter aerial counts of northern Yellowstone elk decreased from approximately 14,500 elk to 9,200 elk during 2000-2003. Ungulates that were sympatric with northern Yellowstone elk included approximately 175-225 bighorn sheep (Ovis canadensis), 700-1,000 bison (Bison bison), $<200$ moose (Alces alces), 100 mountain goats 
(Oreamnos americanus), 2,000-2,500 mule deer (Odocoileus hemionus), 225-250 pronghorn (Antilocapra americana), and a few white-tailed deer (Odocoileus virginianus). The number of wolves residing on the northern range (not including the Sheep Mountain pack outside the park) during early winter 1999-2003 increased from approximately 35 to 98 animals (Smith et al. 2004b). Coyotes (Canis latrans; about 225 animals) were common on the northern range (Crabtree and Sheldon 1999), while grizzly bears (Ursus arctos; about 6070 animals) and black bears (Ursus americanus; unknown abundance) were seasonally abundant during autumn and spring (Haroldson and Frey 2003). Cougars (about 20 adult animals) occurred mostly in the rocky canyons of the Yellowstone River and adjacent drainages and slopes along the Blacktail Deer Plateau and Hellroaring area (Murphy 1998; T. K. Ruth and P. C. Buotte, Wildlife Conservation Society, unpublished data).

Part of the northern Yellowstone elk population migrated outside the park during winter, the extent of which depended on winter severity (Houston 1982). It was legal to harvest these elk during 4 hunts managed by the Montana Department of Fish, Wildlife, and Parks. An archery season, early season backcountry rifle hunt, and general autumn rifle hunt occurred during September through November and focused primarily on bulls. Hunters harvested few adult females during these hunts, which occurred prior to the winter migration of northern Yellowstone elk. In contrast, a limited-access (i.e., permit drawing) late rifle hunt in January-February was highly biased towards harvesting females, with an average of 1,226 antlerless elk (range $=648-2,221)$ legally harvested each year during 1996-2003 (Lemke 2003).

\section{Methods}

We captured adult female elk across the portion of the northern range within Yellowstone National Park using net guns from helicopters (Hawkins and Powers Aviation, Greybull, Wyoming) on 15-16 March 2000, 6-8 February 2001, and 4-5 February 2002. We hobbled, blindfolded, and fit captured elk with either a very high frequency (VHF) or releasable Global Positioning System (GPS) radiocollar equipped with a motion-sensitive mortality sensor that changed pulse rate when the animal was motionless for $>4$ hours. We estimated ages of captured elk using cementum analyses of extracted incisors (2000) or upper canines (2001, 2002; Matson's Laboratory, Milltown, Montana) and used 1-tailed Mann-Whitney tests to compare median ages. We collected blood from elk at time of capture and used pregnancy-specific protein B assays to assess pregnancy status (Wyoming State Veterinary Laboratory, Laramie). We estimated nutritional condition (percent body fat) at capture using ultrasonography and body condition scoring, examining fat, mass, and the thickness of the loin muscle (Cook et al. 2004).

We used a combination of ground-based and aerial radiotelemetry to monitor the survival of radiomarked elk. When we detected a mortality signal, we located the animal and performed a field necropsy to determine cause of death based on condition of the carcass, presence of wounds and subcutaneous hemorrhaging, blood trails, signs of struggle, and evidence of predators such as tracks, scat, predatorspecific wounds, canine spacing, distinctive consumption patterns, bed sites, or guard hairs.

We used an estimator based on 5 monitoring intervals ( JanFeb, Mar-Apr, May-Jun, Jul-Sep, and Oct-Dec) per year (1 Jun-31 May) to estimate annual survival rates because 1) these intervals corresponded with biologically meaningful periods for elk, 2) we could not assign fates to shorter intervals with certainty, 3) we expected probabilities of survival to vary, not only among animals and intervals, but also over time within the intervals we chose, and 4) longer intervals would have necessitated more extensive censoring of our data.

Elk marked prior to an interval and elk marked partway through an interval experienced unequal exposure to risks, and adjustments for unequal exposure would have required an assumption (constant daily survival) that was not justified. Conversely, capture and handling may have caused temporary increases in mortality risks. We eliminated these potential biases by excluding newly marked elk from our risk set until the beginning of the interval succeeding capture and by truncating records for elk with GPS collars at the ends of intervals prior to scheduled collar-recovery dates. Because survival rates tend to be relatively high and consistent for adult female elk $\leq 15$ years of age (White et al. 2003) and our sample included a modest number of very old animals, we computed weighted-average survival rates (years weighted equally) for all elk and for elk $\leq 15$ years of age for the duration of our study. We right-censored survival records for missing elk at the end of the last interval survived to compute maximum survival estimates. We treated missing elk as deaths occurring on the last date observed to compute minimum survival estimates.

When computing survival estimates, we let $i$ and $j$ index intervals (Jan-Feb, Mar-Apr, ..., Oct-Dec) and years (2000, 2001, ..., 2004), respectively. We tallied numbers of elk at risk $\left(n_{i j}\right)$ and numbers of elk that died $\left(d_{i j}\right)$ for each combination of interval and year. We then estimated interval survival as $\hat{s}_{i j}=1-\left(d_{i j} / n_{i j}\right)$ and the weighted average of interval survival rates as $\hat{s}_{i}=\sum_{j} w_{i} \cdot s_{i}$. We specified weights to afford equal influence to each interval estimate contributing to the weighted average. Average annual survival was the product of weighted-average interval estimates. We estimated confidence intervals from percentiles of 1,000 bootstrap replicates with individual elk as resampling units. We used the $\mathrm{R}$ software environment (R Development Core Team 2005) for statistical analyses.

\section{Results}

We captured and radiomarked 93 individual adult female elk, including 45 during March 2000, 28 during February 2001, and 20 (+ 4 recaptures) during February 2002. We excluded 8 elk from our analysis because they did not survive to the start of the interval following capture. Two of these $8 \mathrm{elk}$ died as a direct result of capture; proximate causes of death for the remainder included wolves (4) and cougars (2). Ages of elk when captured ranged from 1 to 18 years (median $=8$ ). 
Table 1. Interval survival rates and causes of death for adult female elk radiocollared in Yellowstone National Park, USA, Mar $2000-F e b 2004$.

\begin{tabular}{|c|c|c|c|c|c|c|c|c|c|c|c|c|}
\hline \multirow[b]{2}{*}{ Interval } & \multirow[b]{2}{*}{ Years } & \multirow{2}{*}{$\begin{array}{l}\text { Elk-intervals } \\
\text { of exposure }\end{array}$} & \multicolumn{4}{|c|}{ Mortalities caused by predators } & \multicolumn{4}{|c|}{ Other documented mortalities } & \multirow{2}{*}{$\begin{array}{c}\text { Interval } \\
\text { survival } \\
\text { rate }\end{array}$} & \multirow{2}{*}{ SE } \\
\hline & & & Wolf & Cougar & Bear & Unknown & Hunting & Winter-kill & Unknown & Missing & & \\
\hline \multicolumn{13}{|c|}{ Fates of all marked elk } \\
\hline Jan-Feb & 4 & 148 & 3 & 0 & 0 & 1 & 11 & 1 & 0 & 2 & 0.89 & 0.026 \\
\hline Mar-Apr & 3 & 150 & 1 & 1 & 0 & 0 & 0 & 1 & 1 & 1 & 0.97 & 0.015 \\
\hline May-Jun & 4 & 186 & 2 & 0 & 1 & 0 & 0 & 0 & 2 & 0 & 0.97 & 0.013 \\
\hline Jul-Sep & 4 & 181 & 1 & 0 & 0 & 1 & 0 & 0 & 0 & 0 & 0.99 & 0.007 \\
\hline Oct-Dec & 4 & 159 & 3 & 0 & 0 & 0 & 0 & 0 & 3 & 1 & 0.96 & 0.016 \\
\hline \multicolumn{13}{|l|}{$\begin{array}{l}\text { Fates of only elk } \\
<16 \text { yr old }\end{array}$} \\
\hline Jan-Feb & 4 & 133 & 1 & 0 & 0 & 0 & 11 & 0 & 0 & 2 & 0.91 & 0.024 \\
\hline Mar-Apr & 3 & 138 & 1 & 1 & 0 & 0 & 0 & 1 & 1 & 1 & 0.97 & 0.016 \\
\hline May-Jun & 4 & 175 & 1 & 0 & 0 & 0 & 0 & 0 & 2 & 0 & 0.98 & 0.012 \\
\hline Jul-Sep & 4 & 161 & 1 & 0 & 0 & 1 & 0 & 0 & 0 & 0 & 0.99 & 0.012 \\
\hline Oct-Dec & 4 & 142 & 3 & 0 & 0 & 0 & 0 & 0 & 1 & 1 & 0.98 & 0.015 \\
\hline
\end{tabular}

Of 85 elk tested, 69 were pregnant $(81 \%, \mathrm{SE}=4.3 \%)$. The 16 elk that were not pregnant included 2 of 3 yearlings and 8 of 15 that were $\geq 15$ years of age (Cook et al. 2004).

At least 33 of 85 elk included in our analysis died during our study, most $(81 \%)$ between December and March (Table 1). We attributed 14 deaths to predation (10 wolf, 2 unknown, 1 cougar, and 1 bear), 11 to hunter harvest, 6 to unknown causes, and 2 to winter-kill. We were unable to determine the fates of $4 \mathrm{elk}$. All of the deaths attributed to predators and 3 attributed to unknown causes occurred inside Yellowstone National Park. The 11 hunter kills and 1 death attributed to unknown causes occurred outside the park.

Weighted average annual survival rates ranged from 0.81 (missing animals counted as deaths; 95\% CI $=0.74-0.87$ ) to 0.83 (missing animals censored; 95\% CI $=0.77-0.89$ ) for females $1-15$ years old and from $0.77(95 \% \mathrm{CI}=0.70-0.83)$ to $0.80(95 \% \mathrm{CI}=0.73-0.86)$ for all females. Interval survival rates (Table 1) were lower during January and February than during other months. Cause-specific rates of annual mortality (deaths per individual) for adult female elk, based on documented causes of death, were 0.09 (0.05-0.14) for predators (including wolves), 0.08 (0.04-0.13) for hunting, and 0.07 (0.03-0.11) for wolves; however, these estimates are conservative and should be interpreted cautiously because fates of study animals and causes of death were not always known.

Elk killed by hunters were younger (median age $=9 \mathrm{yr}$, range $=4-11$ ) than elk killed by wolves (median age $=12 \mathrm{yr}$, range $=9-18 ; U=85, P<0.02)$. However, median ages at capture were also younger $(U=562, P<0.01)$ for elk known to winter primarily outside the park (median $=7 \mathrm{yr}, n=11$ ), where they were exposed to hunting, than for elk that we did not observe outside the park (median $=9 \mathrm{yr}, n=71)$.

\section{Discussion}

Annual survival of the northern Yellowstone elk we studied from 2000 to 2004 was relatively low, and the major mortality factors were human hunting and wolves. Even our highest estimate of survival for prime-aged females (0.83) was substantially lower than the estimated survival rate for 1969-1975 (0.99) when human harvest was low (i.e., <210 elk per year) and wolves were not present (Eberhardt 2002: table 3 using data from Houston [1982]). It was also lower than adult female survival rates (0.91-0.97) reported for other non-hunted elk herds where predator populations were low or nonexistent (e.g., White 1985, Eberhardt et al. 1996, Ballard et al. 2000). Mack and Singer (1993a,b) used estimates of mortality rate based on Houston's (1982) data in their POP-II model predicting the effects of wolf predation and hunter harvests on northern Yellowstone elk. They predicted that with 100 wolves and antlerless harvests reduced by $27 \%$, elk population estimates would be $11-30 \%$ smaller than population estimates without wolves. However, our much lower survival estimate suggests that their model may overestimate population estimates for elk with harvests and wolves.

Our estimates are within the range of survival rates $(0.67$ to 0.90$)$ reported for other hunted elk populations in the western United States (e.g., Freddy 1987, Leptich and Zager 1991, Unsworth et al. 1993, Cole et al. 1997, Ballard et al. 2000, Hamlin and Ross 2002). For example, estimates of annual survival for adult female elk were $0.75-0.83$ in and near Glacier National Park, Montana, USA, during 19901996, following recolonization by wolves (Bureau 1992, Kunkel and Pletscher 1999). In that multiple-prey ecosystem, where wolves selected white-tailed deer over elk, studies attributed mortality to mountain lions $(13 \%)$, hunters $(5 \%)$, wolves $(4 \%)$, and bears $(1.5 \%$; Boyd et al. 1994, Kunkel et al. 1999).

Our cause-specific mortality data suggested that the primary factors limiting the survival of adult female elk during 2000-2003 were human harvest and wolf predation. Prior to wolf restoration in 1995, the primary causes of mortality for adult female northern Yellowstone elk were hunter harvest and winter-kill (Singer et al. 1989, Coughenour and Singer 1996, Taper and Gogan 2002). Predation on adult elk by coyotes, cougars, and grizzly bears was minimal with no detectable limitation on elk abundance (Houston 1982, Gese and Grothe 1995, Murphy 1998, Crabtree and Sheldon 1999, Knight et al. 1999). Winter-kill was not a significant cause of mortality during our study, likely due to relatively mild snow conditions, reduced elk 
densities well below estimated carrying capacity, and high densities of wolves and other predators that removed weakened animals before they succumbed to prolonged undernutrition (Mech et al. 2001). The Montana Department of Fish, Wildlife, and Parks increased anterless elk permits during the 1990s, owing to increased migrations of elk north of the park during and following the winter of 1989 (Lemke 2003). Harvests of antlerless elk during the post-wolf restoration years of 1996-2004 (mean = 1,297; range $=717-2,465)$ remained similar to removals during the pre-wolf restoration years of 1987-1995 (mean = 1,148; range $=273-2,409$ ), although antlerless permits for the lateseason hunt incrementally dropped from 2,882 in 2000 to 1,400 in 2004 , owing to decreasing abundance and low recruitment of elk (Lemke 2003). Thus, harvests of primeaged females have continued to be a primary limiting factor for northern Yellowstone elk since the restoration of wolves.

In addition, the restoration of wolves to Yellowstone National Park has been quite complete, with virtually all winter range of northern Yellowstone elk now occupied by wolves (Smith et al. 2003). The wolf population on the portion of the northern range within the park increased from 31 animals released there in 1995 and 1996 to approximately 98 wolves by December 2003 (Smith et al. 2004b). Elk are the primary year-round prey for wolves in the park, representing $92 \%$ of kills during winters of $1995-$ 2000 (Smith et al. 2004a). Wolf predation has been highly selective, with the age and sex of wolf-killed elk approximating $43 \%$ calves, $28 \%$ adult females, and $21 \%$ adult males (Mech et al. 2001, Smith et al. 2004a). Assuming that $64 \%$ of 12,000 animals were adult females (Houston 1982), the annual offtake by wolves suggested by our radiocollared sample of elk was 230-845 adult female elk/year. This may be a high estimate, given that we only radiocollared elk within the park, where the age structure of adult females tends to be older than animals that migrate to lower elevations near the park boundary or outside the park (Houston 1982, Coughenour and Singer 1996, Cook et al. 2004). Thus, our sample may have included a disproportionate number of older animals. Adult female elk killed by wolves on the northern range have been relatively old, with a mean age of approximately 16 years (Wright et al. 2005).

However, given the high survival rates of prime-aged females in the absence of hunting and major predators and at population levels well below carrying capacity, some of this offtake by wolves was likely additive to pre-wolf restoration mortality factors (White et al. 2003). Just how much of the wolf offtake on the northern herd is additive is still open to conjecture. Recent literature disagrees on the subject (cf. White and Garrott 2005, Vucetich et al. 2005, Varley and Boyce 2006).

Our annual offtake estimate of 230-845 adult female elk translates into approximately 3-10 adult female elk killed per wolf per year for the approximately 85 wolves that resided on the northern range during 2002-2003. This estimate is similar to the 4-7 adult female elk killed per wolf per year predicted by Mack and Singer (1993a:55-58) and the maximum rate of 7 adult female elk killed per wolf per year envisioned by Boyce (1993:241), assuming that $28 \%$ of Boyce's 25 total kills per wolf per year were adult female elk. Comparing our annual kill rate estimates to reported kill rates $(\mathrm{kg} /$ wolf $/ \mathrm{d})$ of various species can check the accuracy of our estimations. The estimated number of adult female elk killed by wolves each year during our study translates to approximately 95,410 kg biomass/year, or $261 \mathrm{~kg} /$ day. This amounts to $3.08 \pm 1.95 \mathrm{~kg} /$ wolf/day for the approximately 85 wolves that resided on the northern range during 20022003. Adult female elk biomass would constitute approximately $48 \%$ of this total based on the composition of kills. Thus, total kill rate for all age and sex classes would amount to $6.4 \pm 4.1 \mathrm{~kg} /$ wolf $/$ day. These figures are similar to those found in Yellowstone National Park during 1998, but less than in 1997, a year of extreme winter severity with an expected above average kill rate (Mech et al. 2001). The figures are also well within the range of those reported elsewhere for several prey species (Mech and Peterson 2003:144). The estimated food requirement for wolves is only $3.25 \mathrm{~kg} /$ day (Peterson and Ciucci 2003), and Smith et al. (2003) estimated that northern range wolves had an average of $3.3 \mathrm{~kg} /$ wolf/day of consumable biomass available to them, excluding removal by scavengers. However, a wolf can eat $10 \mathrm{~kg}$ at a feeding (L. D. Mech, United States Geological Survey, unpublished data) and captive wolves consumed an average of 6.3-6.9 kg/wolf/day after fasting (Kreeger et al. 1997). Our estimated kill rates, even when reduced by $10-20 \%$ for scavenger removal and remains, fall within the range of these values.

Our cause-specific mortality data suggest that the predominant mortality forces are different for elk primarily wintering within the park, where wolf densities are the highest, compared with elk wintering outside the park. These findings are similar to those of White et al. (2003) and Wright et al. (2005) based on analyses of harvest data from the Gardiner Late Elk Hunt and wolf-kill data during 19962002 (Mech et al. 2001, Lemke 2003, Smith et al. 2004a). Our result can be explained by the fact that radiocollared adult female elk wintering within the park experienced no hunter-induced mortality, but strong predation pressure by wolves and other predators affected the older age classes (i.e., median age $=12 \mathrm{yr}$ ). This older age distribution of wolf kills was similar to those in other areas (Carbyn 1983, Huggard 1993a,b, Boyd et al. 1994, Kunkel and Pletscher 1999). In contrast, wolf densities outside the park were substantially lower, reducing potential for predator mortality. However, radiocollared elk occupying the area outside the park during winter were subject to relatively intense hunting mortality, which reduced survival rates and thus reduced the numbers of old animals in the population. The result was that wolves and hunters selected elk from subsets of the population with different age structures.

During our study, mortality removed almost $20 \%$ of adult females annually from the northern Yellowstone population. Consequently, stability of the elk population would have required the annual recruitment of some 34 calves per 100 
adult females, assuming an even calf sex ratio. In contrast, White et al. (2003) reported the recruitment of only 12-14 calves per 100 adult females during 2002-2004 (Fig. 1). In the future, recruitment rates are likely to remain lower than required for population stability, given current adult survival rates. Pregnancy rates of prime-aged northern Yellowstone elk are already high and unlikely to increase substantially (White et al. 2003, Cook et al. 2004). Juvenile survival is likely to remain low in the face of moderate to high predator densities (White et al. 2003, Barber et al. 2005).

\section{Management Implications}

An increase in adult female elk survival could increase the growth rate of the northern Yellowstone elk population. Reducing predation is not feasible because most predation was attributable to wolves within the park, where they are protected. However, managers could manipulate the harvest of northern Yellowstone elk, which occurs outside the park and focuses on prime-aged females. White et al. (2003) concluded that nearly all harvest of adult female elk during 1996-2003 was likely additive because hunters primarily removed prime-aged females with otherwise high survival rates. If hunting is superadditive (elk decline more than harvest rate increases) as one model found (Vucetich et al. 2005), then reducing harvest would have even greater effect. Reducing harvests could be problematic, just as reducing wolves would be. Both park provisions and the Endangered Species Act protect the wolf. Elsewhere, the same problems would plague resource managers, even when wolves are no longer on the Endangered Species List (Boitani 2003:339).

\section{Literature Cited}

Ballard, W. B., H. A. Whitlaw, B. F. Wakeling, R. L. Brown, J. C. DeVos Jr., and M. C. Wallace. 2000. Survival of female elk in northern Arizona. Journal of Wildlife Management 64:500-504.

Barber, S., L. D. Mech, and P. J. White. 2005. Yellowstone elk calf mortality following wolf restoration: bears remain top predator. Yellowstone Science 13(3):37-44.

Boitani, L. 2003. Wolf conservation and recovery. Pages 317-340 in L. D. Mech and L. Boitani, editors. Wolves: behavior, ecology and conservation. University of Chicago, Chicago, Illinois, USA.

Boyce, M. S. 1993. Predicting the consequences of wolf recovery to ungulates in Yellowstone National Park. Pages 234-269 in R. Cook, editor. Ecological issues on reintroducing wolves into Yellowstone National Park. National Park Service Scientific Monograph 22, Denver, Colorado, USA.

Boyd, D. K., R. R. Ream, D. H. Pletscher, and M. W. Fairchild. 1994. Journal of Wildlife Management 58:289-295.

Bureau, M. J. 1992. Mortality and seasonal distribution of elk in an area recently colonized by wolves. Thesis, University of Montana, Missoula, USA.

Carbyn, L. N. 1983. Wolf predation on elk in Riding Mountain National Park, Manitoba. Journal of Wildlife Management 47:963-976.

Cole, E. K., M. D. Pope, and R. G. Anthony. 1997. Effects of road management on movement and survival of Roosevelt elk. Journal of Wildlife Management 61:1115-1126.

Cook, R. C., J. G. Cook, and L. D. Mech. 2004. Nutritional condition of northern Yellowstone elk. Journal of Mammalogy 85:714-722.

Coughenour, M. B., and F. J. Singer. 1996. Elk population processes in Yellowstone National Park under the policy of natural regulation. Ecological Applications 6:573-583.

Crabtree, R. L., and J. W. Sheldon. 1999. Coyotes and canid coexistence. Pages 127-163 in T. W. Clark, A. P. Curlee, S. C. Minta, and P. M. Kareiva, editors. Carnivores in ecosystems: the Yellowstone experience. Yale University, New Haven, Connecticut, USA.
Our study provides no solutions to these problems, but rather offers decision-makers sound biological information on which to base decisions.

\section{Acknowledgments}

The Biological Resources Division of the United States Geological Survey, the National Geographic Society, the National Park Service, the National Science Foundation grant 078130 to P. Turchin, J. Fryxell, M. Turner, M. Boyce, and E. Merrill, and the Natural Sciences and Engineering Research Council of Canada financed this study. Special thanks to D. Smith for contributing to the effective and efficient implementation of the project. We also thank S. M. Barber, M. S. Boyce, W. G. Brewster, S. Chin, T. Clark, D. S. Guernsey, Hawkins and Powers Aviation, D. Ireland, D. M. Kirchhof, J. S. Mao, W. Maples, Montana Aircraft, S. T. Olliff, R. O. Peterson, G. E. Plumb, D. R. Stahler, L. M. Thurston, J. Treanor, J. D. Varley, N. Varley, G. J. Wright, and T. Wyman for assisting with capture, data collection, and administration of the project. Biologists from the Montana Department of Fish, Wildlife, and Parks, National Park Service (Yellowstone National Park), United States Forest Service (Gallatin National Forest), and United States Geological SurveyNorthern Rocky Mountain Science Center, Bozeman, as part of the Northern Yellowstone Cooperative Wildlife Working Group, conducted annual trend counts and classifications of northern Yellowstone elk. C. Heydon provided estimates of daily snow water equivalent for the Tower Falls Climate Impact Meteorological station.

Despain, D. G. 1990. Yellowstone vegetation. Robert Rinehart, Boulder, Colorado, USA.

Eberhardt, L. E., L. L. Eberhardt, B. L. Tiller, and L. L. Caldwell. 1996. Growth of an isolated elk population. Journal of Wildlife Management 60:369-373.

Eberhardt, L. L. 2002. A paradigm for population analysis of long-lived vertebrates. Ecology 83:2841-2854.

Farnes, P. E., C. L. Heydon, and K. J. Hansen. 1999. Snowpack distribution across Yellowstone National Park. Final report CA 12681-9017, Department of Earth Sciences, Montana State University, Bozeman, USA.

Freddy, D. J. 1987. The White River elk herd: a perspective, 1960-85. Colorado Division of Wildlife Technical Publication 37, Fort Collins, USA.

Garrott, R. A., L. L. Eberhardt, P. J. White, and J. Rotella. 2003. Climate-induced limitation of a large herbivore population. Canadian Journal of Zoology 81:33-45.

Garrott, R. A., J. A. Gude, E. J. Bergman, C. Gower, P. J. White, and K. L. Hamlin. 2005. Generalizing wolf effects across Yellowstone area: a cautionary note. Wildlife Society Bulletin 33:1245-1255.

Gese, E., and S. Grothe. 1995. Analysis of coyote predation on deer and elk during winter in Yellowstone National Park, WY. American Midland Naturalist 133:36-43.

Hamlin, K. L., and M. S. Ross. 2002. Effects of hunting regulation changes on elk and hunters in the Gravelly-Snowcrest Mountains, Montana. Federal Aid Project W-154-R, Montana Fish, Wildlife, and Parks, Wildlife Division, Helena, USA.

Haroldson, M. A., and K. Frey. 2003. Grizzly bear mortalities. Pages 2428 in C. C. Schwartz and M. A. Haroldson, editors. Yellowstone grizzly bear investigations: annual report of the Interagency Grizzly Bear Study Team, 2002. U.S. Geological Survey, Bozeman, Montana, USA.

Houston, D. B. 1982. The northern Yellowstone elk. Macmillan, New York, New York, USA. 
Huggard, D. J. 1993a. Prey selectivity of wolves in Banff National Park: I. Prey species. Canadian Journal of Zoology 71:130-139.

Huggard, D. J. 1993b. Prey selectivity of wolves in Banff National Park: II. Age, sex, and condition of elk. Canadian Journal of Zoology 71 : 140-147.

Knight, R. R., B. M. Blanchard, and P. Schullery. 1999. Yellowstone bears. Pages 51-76 in T. W. Clark, A. P. Curlee, S. C. Minta, and P. M. Kareiva, editors. Carnivores in ecosystems: the Yellowstone experience. Yale University, New Haven, Connecticut, USA.

Kreeger, T. J., G. D. DelGiudice, and L. D. Mech. 1997. Effects of fasting and refeeding on body composition of captive gray wolves (Canis lupus). Canadian Journal of Zoology 75:1549-1552.

Kunkel, K. E., and D. H. Pletscher. 1999. Species-specific dynamics of cervids in a multipredator ecosystem. Journal of Wildlife Management 63:1082-1093.

Kunkel, K. E., T. K. Ruth, D. H. Pletscher, and M. G. Hornocker. 1999. Winter prey selection by wolves and cougars in and near Glacier National Park, Montana. Journal of Wildlife Management 63:901910.

Lemke, T. O. 2003. Gardiner late elk hunt annual report. Montana Fish, Wildlife and Parks, Livingston, USA.

Lemke, T. O., J. A. Mack, and D. B. Houston. 1998. Winter range expansion by the northern Yellowstone elk herd. Intermountain Journal of Sciences 4:1-9.

Leptich, D. J., and P. Zager. 1991. Road access management effects on elk mortality and population dynamics. Pages 126-131 in A. G. Christensen, L. J. Lyon, and T. N. Lonner, compilers. Proceedings of Elk Vulnerability Symposium, 10-12 April 1991, Montana State University, Bozeman, USA.

Mack, J. A., and F. J. Singer. 1993a. Using Pop-II models to predict effects of wolf predation and hunter harvests on elk, mule deer, and moose on the northern range. Pages 49-74 in R. S. Cook, editor. Ecological issues on reintroducing wolves into Yellowstone National Park. U.S. Department of Interior National Park Service Scientific Monograph NPS/NRYELL/NRSM-93/22, Denver, Colorado, USA.

Mack, J. A., and F. J. Singer. 1993b. Population models for elk, mule deer, and moose on Yellowstone's northern winter range. Pages 270-305 in R. S. Cook, editor. Ecological issues on reintroducing wolves into Yellowstone National Park. U.S. Department of Interior National Park Service Scientific Monograph NPS/NRYELL/NRSM-93/ 22, Denver, Colorado, USA

Mech, L. D. 1970. The wolf: the ecology and behavior of an endangered species. Natural History, Garden City, New York, USA.

Mech, L. D., and R. O. Peterson. 2003. Wolf-prey relations. Pages 131-157 in L. D. Mech, and L. Boitani, editors. Wolves: behavior, ecology, and conservation. University of Chicago, Chicago, Illinois, USA.

Mech, L. D., D. W. Smith, K. M. Murphy, and D. R. MacNulty. 2001. Winter severity and wolf predation on a formerly wolf-free elk herd. Journal of Wildlife Management 65:998-1003.

Murphy, K. M. 1998. The ecology of the cougar (Puma concolor) in the Northern Yellowstone Ecosystem: interactions with prey, bears and humans. Dissertation, University of Idaho, Moscow, USA.
National Research Council. 2002. Ecological dynamics on Yellowstone's northern range. National Academy, Washington, D.C., USA.

Northern Yellowstone Cooperative Wildlife Working Group. 2003. Annual report. Unpublished report issued October 27, 2003, by the National Park Service (Yellowstone National Park), Montana Fish, Wildlife, and Parks, U.S. Forest Service (Gallatin National Forest), and U.S. Geological Survey (Northern Rocky Mountain Science Center). Copy on file at the Yellowstone Center for Resources, Yellowstone National Park, Wyoming, USA.

Peterson, R. O., and P. Ciucci. 2003. The wolf as a carnivore. Pages 104130 in L. D. Mech and L. Boitani, editors. Wolves: behavior, ecology and conservation. University of Chicago, Chicago, Illinois, USA.

R Development Core Team. 2005. R: a language and environment for statistical computing. R Foundation for Statistical Computing, Vienna, Austria. <http://www.r-project.org/>. Accessed 2006 Sep 13.

Singer, F. J., W. Schreir, J. Oppenheim, and E. O. Garton. 1989. Drought, fires and large mammals. BioScience 39:716-722.

Smith, D. W., T. D. Drummer, K. M. Murphy, D. S. Guernsey, and S. B. Evans. 2004a. Winter prey selection and estimation of wolf kill rates in Yellowstone National Park, 1995-2000. Journal of Wildlife Management 68:153-166.

Smith, D. W., R. O. Peterson, and D. B. Houston. 2003. Yellowstone after wolves. BioScience 53:330-340.

Smith, D. W., D. R. Stahler, and D. S. Guernsey. 2004b. Yellowstone Wolf Project: annual report, 2003. National Park Service, Yellowstone Center for Resources YCR-NR-2004-04, Yellowstone National Park, Wyoming, USA.

Taper, M. L., and P. J. P. Gogan. 2002. The northern Yellowstone elk: density dependence and climatic conditions. Journal of Wildlife Management 66:106-122.

Unsworth, J. W., L. Kuck, M. D. Scott, and E. O. Garton. 1993. Elk mortality in the Clearwater drainage of northcentral Idaho. Journal of Wildlife Management 57:495-502.

Varley, N., and M. S. Boyce. 2006. Updating model projections for Yellowstone wolf recovery. Ecological Modelling 193:315-339.

Vucetich, J. A., D. W. Smith, and D. R. Stahler. 2005. Influence of harvest, climate and wolf predation on Yellowstone elk, 1961-2004. Oikos 111:259-270.

White, G. C. 1985. Survival rates of wapiti (Cervus elaphus nelsoni) in the Jemez Mountains, New Mexico, USA. Royal Society of New Zealand, Biology of Deer Production 22:51-54.

White, P. J., and R. A. Garrott. 2005. Northern Yellowstone elk after wolves. Wildlife Society Bulletin 33:942-955.

White, P. J., R. A. Garrott, and L. L. Eberhardt. 2003. Evaluating the consequences of wolf recovery on Northern Yellowstone elk. National Park Service, Yellowstone Center for Resources YCR-NR-20040-02, Yellowstone National Park, Wyoming, USA.

Wright, G. J., R. O. Peterson, D. W. Smith, and T. O. Lemke. 2006. Selection of northern Yellowstone elk by gray wolves and hunters. Journal of Wildlife Management 70:in press.

Associate Editor: Hudson. 